\title{
Determinants of the adoption of conservation practices by farmers in the Northwest Wheat and Range Region
}

\author{
N.S.P. Tosakana, L.W. Van Tassell, J.D. Wulfhorst, J. Boll, R. Mahler, E.S. Brooks, and S. Kane
}

\begin{abstract}
A survey of over 1,500 farmers located in northern Idaho and eastern Washington was conducted to examine conservation practices, attitudes, and perceptions. As part of this survey, farmers were asked to identify their adoption of gully plugs and buffer strips. Buffer strips were used by just over half of the farmers. Between $39 \%$ and $28 \%$ of respondents, depending on land slope, used gully plugs. An ordered logit model was used to predict the probability of adoption of each conservation practice and to identify key variables affecting farmers' decisions to invest in those practices. The perceived effectiveness of the conservation practice had the greatest impact on adoption, while levels of education, years managing farms, and whether or not the respondent was farming full-time had little impact on these conservation decisions. The larger the acreage being farmed, the more likely the respondent was to invest in gully plugs. Almost half of the farmland was leased, which proved more of a deterrent to the adoption of gully plugs than buffer strips. The financial stress of the respondent and the cost of structure implementation were less important factors in the implementation of gully plugs and buffer strips. Conversely, the maintenance of these conservation practices, particularly buffer strips, was an important consideration in their adoption. Results of this survey and comments made by respondents indicate a keen interest by farmers in conservation issues. The importance of changing farmer's perceptions of the effectiveness of conservation practices was clearly identified in this study. Maintaining observation sites for several years may be a valuable asset in changing perceptions as farmers are able to witness the dynamic impact of conservation practices. Educational programs and materials focusing on conservation should likewise target off-farm landowners given the large percentage of the farmland that is leased in this region.
\end{abstract}

Key words: adoption — conservation practices—social indicators—-water quality

Over the past several decades, various government programs have been introduced to entice farmers to adopt management practices to assist in controlling nonpoint source pollution. Programs like the Environmental Quality Incentive Program of the USDA Natural Resource Conservation Service (NRCS) have encouraged farmers to adopt best management practices by offering financial and technical assistance to qualified participants farming eligible agricultural land. Despite such programs, best management practice adoption has met with varying success.

Pannell et al. (2006) hypothesized that the adoption of conservation practices occurs size was significantly positive in 7 , significantly negative in 3 , and insignificant in 11 . They concluded that studies aimed at promoting conservation agriculture must target conditions of the individual locales.

The Northwest Wheat and Range Region (NWRR) is one of the most erosion-prone regions of the United States, especially when considering the Palouse region, where slopes on cultivated land average $15 \%$ to $20 \%$ and intermediately reach 50\% (Dillman and Carlson 1982). Combined with the highly erodible loess soils, relatively ample moisture (upwards of $75+\mathrm{cm}[30+$ in] of annual precipitation), and a rotation of cereal grains and annual legumes, these steep slopes are a major contributor to the sediment that impairs the NWRR streams, rivers, and lakes.

Over a 15-year period, Carlson et al. (1994) studied changes in attitudes and behaviors of NWRR farmers regarding soil erosion and found an increased awareness of the problems associated with soil erosion and an increased use of erosion control practices. From their 1976 survey, they found that background variables such as education and farm size were significantly related to the adoption of erosion control practices. In their 1989 to 1990 study (Carlson et al. 1994), ecological and attitudinal factors, measured as erosion concern and erosion attitude scales, were more salient than in the 1976 survey. The increase in societal pressure between the two study periods was thought to be an important factor affecting the attitude of farmers.

Along with the adoption of more erosionreducing tillage techniques, gully plugs and buffer strips are two of the most promising soil loss abatement practices in the NWRR. Gully plug is a regional term that can describe a water and sediment control basin, grade stabilization structure, and/or sediment basin practice. In the NWRR, gully plugs personal goals (economic, social, and environmental) will be met, if the innovation is viewed as superior to its predecessor, and the innovation is easy to test and learn about. In an analysis of 55 studies conducted in the United States, Prokopy et al. (2008) concluded that younger producers with diverse farming operations, higher education levels, access to labor, and those that have more acreage, income, and capital, were more likely to adopt conservation practices. Knowler and Bradshaw (2007), however, found that few universal variables explain the adoption of conservation practices on a regular basis. For example, in their review of 23 articles, farm
Naga S.P. Tosakana is a PhD student in Environmental Science, J.D. Wulfhorst is an associate professor in Agricultural Economics and Rural Sociology, Jan Boll is a professor in Biological and Agricultural Engineering, Robert Mahler is a professor in Plant, Soil and Entomological Sciences, Erin S. Brooks is a research scientist in Biological and Agricultural Engineering, and Stephanie Kane is the project manager of the Social Science Research Unit, University of Idaho, Moscow, Idaho. Larry W. Van Tassell is a professor and department head of the Department of Agricultural Economics, University of Nebraska, Lincoln, Nebraska. 
consist of a sediment basin to capture water that would otherwise erode down a hillside. A stand pipe in the basin leads to a conveyance pipe that transports runoff water to a nearby body of water. Buffer (or filter) strips are areas where erosion resistant vegetation has been planted to allow the transportation of water down a slope with minimal soil erosion. Both of these conservation structures have been promoted by the USDA NRCS through the Environmental Quality Incentive Program, although adoption of these structures has met with varied success through this program. Farmers at times install gully plugs without government assistance because they prefer not to follow NRCS guidelines, feeling those guidelines result in oversized and/or over-engineered structures (Latah County NRCS office, personal communication, January 27, 2010), increasing initial costs and making maintenance and farming practices more cumbersome. Many buffer strips are developed and maintained to not only prevent erosion but because the buffered area can be too wet to farm.

An understanding of how farmers make adoption decisions is important in the promotion and assessment of government conservation policy. Conservation programs developed and implemented on the basis of incorrect assumptions about factors affecting conservation adoption at the farm level can be ineffective. This study will assess farm, demographic, attitudinal, and economic characteristics of agricultural producers to determine the characteristics that lead to, or away from, the adoption of conservation practices in the NWRR, specifically gully plugs and buffer strips.

\section{Materials and Methods}

Data. A survey of NWRR farmers located across portions of seven counties in northern Idaho and three counties in eastern Washington was conducted to determine their conservation attitudes, practices, and perceptions. The sampling frame was constructed by compiling university extension office lists from each of the counties in the region. The lists were merged, and duplicate listings and zip codes outside the target geographical region were removed.The resulting frame contained 2,275 addresses. A simple random sample of 1,504 households was drawn using the SurveySelect procedure in SAS Institute (2006). The sample was drawn proportionate to representation in the frame.
The survey was administered by the Social Science Research Unit located at the University of Idaho and was conducted from December 2006 to March 2007. An eight-page survey was mailed to each household following the Dillman survey method (Dillman 1978, 2000). After adjusting for ineligible and nondeliverable surveys, a $55.1 \%$ response rate was obtained, providing 553 completed surveys.

Empirical Model. An ordered probit model (Greene 2000) was used to predict the probability of adoption of gully plugs and buffer strips on various landscapes or slopes. The model identified key variables affecting farmers' adoption decisions, with the trivariate outcome depending on field attributes, operator socioeconomic characteristics and attitudes, and farm attributes.

Empirically, the model for gully plug adoption can be written as

GPuse $_{i}=f\left(\right.$ GPeffect $_{i j}, \%$ Slope $_{i}$, ED, MANAGE, FT, TOTAC, FINSTRESS, IMPLEMENT, MAINTENANCE, REGULATION, \%LEASED, XLESSOR, XRISK, HERITAGE, PROFIT),

and for buffer strip adoption is

BSuse $_{i}=f\left(\right.$ BSeffect $_{i}, \%$ Slope $_{i}$, ED, MANAGE, FT, TOTAC, FINSTRESS, IMPLEMENT, MAINTENANCE, REGULATION, \%LEASED, XLESSOR, XRISK, HERITAGE, PROFIT),

where all variables are as defined in table 1.

The dependent variables, GPuse ${ }_{i}$ and BSuse $_{i}$, are measures of the adoption of gully plugs and buffer strips, respectively, for various landscapes or land slopes. Three slope levels $(i=\mathrm{S}, \mathrm{M}, \mathrm{H})$ are defined as slight $(0 \%$ to $5 \%)$, moderate $(6 \%$ to $15 \%)$, and high $(>15 \%)$, respectively. The trivariate categories of adoption, or frequency of use, on the respondent's land were presented in the survey as none, some, and often, with each level specified in the multinomial logit model as 0 , 1 , and 2 , respectively.

The adoption of the two conservation practices in question is postulated to be influenced by the effectiveness of the conservation practices themselves, various demographic, economic, and attitudinal characteristics of the respondents, and the physical characteristics of the farm. Following Pannell et al. (2006), we hypothesize that if farmers per- ceive that a conservation practice will not be effective, they will be less likely to adopt that practice. As part of the survey, respondents were asked to identify the perceived effectiveness of gully plugs (GPeffect $t_{\mathrm{ij}}$ ) and buffer strips $\left(\mathrm{BSeffect}_{\mathrm{ij}}\right)$ for each of the $i(i=\mathrm{S}, \mathrm{M}$, $\mathrm{H})$ slope landscapes defined for the independent variables. Effectiveness was judged using $j$ rankings of 1 (low), $\mathrm{m}$ (medium), and $\mathrm{h}$ (high). This provided three variables for each equation, with each variable specified as 1 equals effectiveness specified at that level, 0 otherwise. To avoid singularity, the medium effectiveness level variable was omitted, leaving a variable for low effectiveness and one for high effectiveness in the equation.

The farm characteristics hypothesized to influence the adoption of gully plugs and buffer strips include total acreage being farmed and the percent of that acreage that is leased. The larger the farming operation in terms of acreage (TOTAC), the more likely that farmers will adopt conservation practices (Lamba et al. 2009; Robinson and Napier 2002). The more acreage managed, the more likely that farmers also will have areas that are environmentally sensitive and are in need of conservation structures. There may also be economies of size attached to the implementation of conservation practices. For example, a larger-sized farm would be more likely to have the equipment required for the implementation of the practices.

We hypothesize that the percentage of leased land (\%LEASED) negatively impacts the adoption of gully plugs and buffer strips. Individuals farming leased land are thought to have a shorter-term planning horizon and to be less willing to invest in long-term conservation practices (Soule et al. 2000). Lessors may also purchase land with the intent of earning a return on investment and view less favorably the adoption of conservation practices that do not contribute to those returns.

The demographics considered include education level, farm management experience, and current involvement in farming. Prokopy et al. (2008) categorized these as human capital variables and stated they increase the capacity of farmers to adopt conservation practices.

Education (ED) is hypothesized to have a positive relationship with the use of gully plugs and buffer strips. Studies by Dasgupta et al. (2007), Asafu-Adjaye (2008), Paudel et al. (2008), and Wu and Babcock (1998) found that farmers' education tends to positively influence their decision to adopt conservation. 


\section{Table 1}

Description of the independent and dependent variables used to assess the frequency of use of conservation structures.

\begin{tabular}{|c|c|}
\hline Variable & Description \\
\hline \multicolumn{2}{|c|}{ Dependent variables } \\
\hline GPuse $_{i}$ & $\begin{array}{l}\text { Frequency of use }(0=\text { none, } 1=\text { some, } 2=\text { often) of gully plugs on land with } i \text { slope, where } i=\mathrm{S} \text { (none-to-slight } \\
[0 \% \text { to } 5 \%]), \mathrm{M} \text { (moderate }[6 \% \text { to } 15 \%]) \text {, or } \mathrm{H} \text { (high }[>15 \%])\end{array}$ \\
\hline BSuse $_{i}$ & $\begin{array}{l}\text { Frequency of use }(0=\text { none, } 1=\text { some, } 2=\text { often) of buffer strips on land with } i \text { slope, where } i=\mathrm{S} \text { (none-to-slight } \\
[0 \% \text { to } 5 \%]), \mathrm{M}(\text { moderate }[6 \% \text { to } 15 \%]) \text {, or } \mathrm{H}(\text { high }[>15 \%])\end{array}$ \\
\hline \multicolumn{2}{|c|}{ Independent variables } \\
\hline GPeffect $_{i j}$ & $\begin{array}{l}\text { Respondents' perceived effectiveness of gully plugs on land with } i \text { slope, where } i=\mathrm{S} \text { (none-to-slight [0\% to } 5 \%] \text { ), } \mathrm{N} \\
\text { (moderate [6\% to } 15 \%] \text { ), or } \mathrm{H} \text { (high }[>15 \%] \text { ), and } \mathrm{j}=\mathrm{I}(\mathrm{low}), \mathrm{m} \text { (medium), } \mathrm{h} \text { (high) level of effectiveness. Each vari } \\
\text { able is specified as } 1=\text { effectiveness is perceived at that level, } 0=\text { otherwise. To avoid singularity, the } \mathrm{j}=\mathrm{m} \text { varia } \\
\text { was omitted from each equation }\end{array}$ \\
\hline BSeffect $_{i j}$ & $\begin{array}{l}\text { Respondents' perceived effectiveness of buffer strips on land with } i \text { slope, where } i=\mathrm{S} \text { (none-to-slight [0\% to } 5 \%] \text { ), } \\
\text { (moderate [6\% to } 15 \%] \text { ), or } \mathrm{H} \text { (high }[>15 \%] \text { ), and } \mathrm{j}=\mathrm{I}(\mathrm{low}), \mathrm{m} \text { (medium), } \mathrm{h} \text { (high) level of effectiveness. Each vari } \\
\text { able is specified as } 1=\text { effectiveness is perceived at that level, } 0=\text { otherwise. To avoid singularity, the } \mathrm{j}=\mathrm{m} \text { varia } \\
\text { was omitted from each equation }\end{array}$ \\
\hline TOTAC & Total acres farmed, both owned and leased \\
\hline$\%$ LEASED & Percentage of farmland that is leased \\
\hline$E D$ & Number of years of education received; continuous variable ranging from 1 to 20 , with $12=$ high school degree \\
\hline MANAGE & Years managing a farm operation \\
\hline FT & Current involvement in farming, with full-time $=1$ and part-time $=0$ \\
\hline FINSTRESS & $\begin{array}{l}\text { Financial stress currently experienced by the farmer, with } 1=\text { insignificant } / \text { none, } 2=\text { slight, } 3=\text { average, } 4=\text { abov } \\
\text { average, } 5=\text { severe }\end{array}$ \\
\hline IMPLEMENT & $\begin{array}{l}\text { Importance the cost of implementing conservation practices plays in the farmer's conservation decisions, with } \\
1=\text { important or very important, } 0=\text { not or somewhat important }\end{array}$ \\
\hline MAINTENANCE & $\begin{array}{l}\text { Importance the cost of maintaining conservation practices plays in the farmer's conservation decisions, with } 1= \\
\text { important or very important, } 0=\text { not or somewhat important }\end{array}$ \\
\hline PROFIT & $\begin{array}{l}\text { Respondents' agreement with the statement that profitability is their greatest concern when considering a } \\
\text { conservation decision, with } 1 \text { = agree or strongly agree, } 0=\text { disagree or strongly disagree }\end{array}$ \\
\hline REGULATION & $\begin{array}{l}\text { Respondents' agreement with the statement that conservation structures have regulatory requirements that mak } \\
\text { stallation and management more effort than the possible off-site benefits gained, with } 1 \text { = agree or strongly agre } \\
0=\text { disagree or strongly disagree }\end{array}$ \\
\hline HERITAGE & $\begin{array}{l}\text { Respondents' agreement with the statement that they hope to have their children continue farming their operatio } \\
\text { with } 1=\text { agree or strongly agree, } 0=\text { disagree or strongly disagree }\end{array}$ \\
\hline LESSOR & $\begin{array}{l}\text { For leased land, the importance to the farmer's conservation decisions of the lessor's willingness to invest in } \\
\text { conservation practices, with } 1=\text { not important, } 2=\text { somewhat important, } 3=\text { important, } 4=\text { very important }\end{array}$ \\
\hline XLESSOR & Interaction term between \%LEASED and LESSOR \\
\hline LRISK & $\begin{array}{l}\text { For leased land, the importance to the farmer's conservation decisions of the risk of not continuing with the land } \\
\text { lease, with } 1=\text { not important, } 2=\text { somewhat important, } 3=\text { important, } 4=\text { very important }\end{array}$ \\
\hline XRISK & Interaction term between \%LEASED and LRISK \\
\hline
\end{tabular}

The respondents' farming experience, as measured by the number of years they have been managing a farm (MANAGE), is hypothesized to positively influence the use of gully and buffer strips. As the level of experience increases, it is more likely the farmers will understand the consequences of environmental degradation and the anticipated value of the conservation practices in question to mitigate erosion. Also, the longer the farmers have been managing, the more expertise they should have, allowing them to implement and manage such practices (Dasgupta et al. 2007; Asafu-Adjaye 2008; Paudel et al. 2008).

We hypothesize that if the respondents are farming full-time, as compared to part-time (FT), they are more likely to adopt conservation practices (Prokopy et al. 2008). This hypothesis follows the reasoning that fulltime farmers are investing more time and energy into the farming process and are more apt to pursue government programs that will assist in conservation adoption.
Economic considerations include the financial stress currently experienced by farm operators, the importance of the cost of implementing and maintaining conservation practices in their adoption, and the importance profitability plays when a conservation decision is being analyzed. Several studies have indicated that higher farm income and/or lower financial stress will have a positive influence on adoption of conservation practices (Asafu-Adjaye 2008; Paudel et al. 2008; Lamba 2009). Similarly, we hypoth- 
esize higher financial stress (FINSTRESS) will have a negative influence on the adoption and investment process. The higher the financial stress experienced by farmer, the less cash flow will be available to finance conservation practices. Farmers under financial duress will most likely focus on ways they can increase their short-term profitability and be less likely to examine long-term conservation investments. Likewise, we hypothesize a negative relationship between farmers' profit maximizing goals (PROFIT) and the adoption of gully plugs and buffer strips.

If the cost of implementing a conservation practice is high (IMPLEMENT), farmers are hypothesized to be less likely to adopt the conservation practice unless they have other incentives to do so. We also hypothesize that the higher the cost of maintaining the conservation structure (MAINTENANCE), the less likely they are to adopt the conservation practice.

Respondents' attitudes or opinions regarding several conservation issues may prove insightful in determining their willingness to invest in gully plugs and buffer strips. The attitudinal factors examined in this study include the lessor's willingness to invest in conservation practices, the risk of losing a land lease, and the desire of the respondent to have children continue farming their operation.

When farmers enroll in a government financial assistance program for implementing conservation structures on their properties, they are not free to place the structure how and where they would like but must comply with the technical recommendations that accompany that assistance. Some farmers may find the federal requirements objectionable and be less likely to participate in the conservation program. To test this attitude with respect to gully plugs and buffer strips, the variable REGULATION was incorporated in the analysis. This variable was created from the survey question that asked respondents to disagree or agree with the statement that "conservation structures have regulatory requirements that make installation and management more effort than the possible off-site benefits gained." This question assumes farmers in the NWRR recognize and value the off-site benefits of their actions. This assumption might be justified by the fact that many of the farmers transport their grain via barge on the Snake and Columbia River system and are aware of the problems associated with sedimentation filling the rivers and dams along the rivers. Salmon recovery and recreation issues also keep the impacts of their conservation decisions in the forefront

Many conservation measures are not only undertaken to ensure water quality but to also maintain soil integrity for future generations (Rahelizatovo and Gillespie 2004; Kim et al. 2005). We hypothesize that this attitude (HERITAGE) will have a positive impact on the adoption of gully plugs and buffer strips.

Timmons (1980) hypothesized that absentee landlords have a strong preference for current income and, therefore, have a short-term, rather than a long-term, planning horizon when assessing the benefits of investing in conservation practices. Lee and Stewart (1983) indicated the importance of the landowner's involvement in long-term investments, such as grassed waterways, gully plugs, and terraces. To test the significance of the lessor's involvement in the conservation process, the variable LESSOR represented the importance of the lessor's willingness to invest in conservation practices, with $1=$ not important, $2=$ somewhat important, $3=$ important, and $4=$ very important. Because not all respondents farmed leased land, an interaction term was developed between LESSOR and \%LEASED. This provided the continuous variable XLESSOR, which was 0 if the respondent did not lease farmland and increased linearly with the percentage of land leased and the importance placed on the lessor's willingness to invest in conservation practices.

Norris and Batie (1987) found that the shorter term the lease on rented land, the less incentive the lessee has to maintain the productivity of the land. Based on this premise, we hypothesize that the greater the risk of losing a lease, the less a farmer is inclined to invest in gully plugs or buffer strips. Respondents were asked to state the importance that the risk of not continuing with the land lease had on their conservation decisions (LRISK), with 1 = not important, $2=$ somewhat important, $3=$ important, and $4=$ very important. As with the LESSOR variable, XRISK was developed by multiplying LRISK by \%LEASED, creating a variable that was 0 if the respondent did not lease farmland and that increased linearly with the percentage of land leased and the importance placed on the uncertainty of the lease.

\section{Results and Discussion}

Average respondents were 57 years old and had been living in the region for 54 years. They had been managing a farm operation for 29 years, and 74\% described their current involvement in farming as full-time. Four percent of the respondents had not completed a high school education, and almost $44 \%$ had four years or more of education past their high school degrees.

The most common crop grown in the area was winter wheat (Triticum aestivum), followed by spring wheat (Triticum aestivum), peas (Pisum sativum), barley (Hordeum vulgare), Kentucky bluegrass (Poa pratensis L.), and canola (Brassica napus). The average farm size was 645 ha $(1,594 \mathrm{ac})$, with the largest operation being 9,915 ha $(24,500 \mathrm{ac})$ and the smallest being 3 ha $(8 \mathrm{ac})$. The percentage of leased land averaged almost $48 \%$, with $32 \%$ of respondents not leasing any land and almost $17 \%$ leasing all of the land they farm. Of those leasing $100 \%$ of their land, the average size of lease was 591 ha $(1,460 \mathrm{ac})$, with a range of 32 to 2,914 ha ( 80 to $7,200 \mathrm{ac}$ ). Respondents estimated that $28 \%$ of their land had none-to-slight ( $0 \%$ to $5 \%$ ) slope, $49 \%$ was labeled as being under a moderate (6\% to $15 \%$ ) slope, and $32 \%$ was estimated to have a high (>15\%) slope.

Most respondents leasing farmland felt that the landowner's willingness to invest in conservation practices was important or very important in their conservation decisions (table 2). These results closely mirrored the percentage of respondents who felt the risk of not continuing with a land lease was important to their conservation decisions. The difference was that more respondents felt the risk of losing their lease was very important, compared to those who felt it was important (table 2).

The cost of implementing conservation practices was important or very important to the respondent's decision regarding conservation practices (table 2). When asked about how important the cost of implementation and the cost of maintenance were in making conservation investment decisions, most respondents indicated the cost of implementation was important or very important and that the cost of maintenance was likewise important to them (table 2). While respondents tended to feel that the cost of implementing and maintaining conservation practices was an important consideration in conservation decisions, they were not quite 
Table 2

Respondents rating of each factor according to their level of importance in their conservation decisions.

\begin{tabular}{|c|c|c|c|c|}
\hline Factor & $\begin{array}{l}\text { Not } \\
\text { important (\%) }\end{array}$ & $\begin{array}{l}\text { Somewhat } \\
\text { important (\%) }\end{array}$ & Important (\%) & $\begin{array}{l}\text { Very } \\
\text { important (\%) }\end{array}$ \\
\hline The cost of implementing conservation practices & 2 & 14 & 47 & 37 \\
\hline Risk of not continuing with the land lease & 12 & 22 & 29 & 37 \\
\hline Landowner's willingness to invest in conservation practices & 14 & 28 & 41 & 17 \\
\hline
\end{tabular}

\section{Table 3}

Respondents rating of each factor according to their level of importance in their conservation decisions.

\begin{tabular}{lccc}
\hline Factor & $\begin{array}{l}\text { Strongly } \\
\text { disagree (\%) }\end{array}$ & Disagree (\%) & $\begin{array}{l}\text { Strongly } \\
\text { agree (\%) }\end{array}$ \\
\hline $\begin{array}{l}\text { Conservation structures have regulatory requirements that make installation } \\
\text { and management more effort than the possible off-site benefits gained }\end{array}$ & 4 & 32 & 53 \\
Profitability is my greatest concern when considering a conservation decision & 3 & 35 & 11 \\
My hope is to have my children continue farming my operation & 11 & 21 & 31
\end{tabular}

as strong in their opinion that profitability was their greatest concern when considering conservation decisions (table 3). Over 46\% of respondents stated they were experiencing above average or severe financial stress, while $19 \%$ felt their financial stress was slight to none.

Regulatory requirements regarding the installation of conservation structures are often attached to farmer financial incentive programs. The majority of respondents agreed or strongly agreed that regulatory requirements associated with conservation structures make installation and management more effort than the possible off-site benefits gained from investing in the structure (table 3 ).

The majority of respondents had desires that their children continue farming their operation (table 3). Feelings regarding this hope did not statistically differ (chi-square test with $p<0.05$ ) between respondents who farmed their own land and those who leased greater than $50 \%$ of their land.

The majority of respondents did not use gully plugs on their land, regardless of slope (table 4), and they generally perceived their effectiveness to be low. Gully plugs were used slightly more on moderately sloped land compared to land with a high slope, although their perceived overall effectiveness was numerically greater for the highersloped land. Gully plugs are more likely to be used on moderately sloped land because there is a limited water storage area on steep slopes (Latah County NRCS office, personal communication, January 27, 2010).
Buffer strips were used more by respondents across all landscapes (table 4) than were gully plugs and were used as frequently for moderately sloped land as for highly sloped land.The effectiveness of buffer strips also was rated higher by respondents than the effectiveness of gully plugs across all landscapes.

Effects of Explanatory Variables on Adoption. Ordered logit models were estimated using LIMDEP (Greene 2002) to capture the effect of different explanatory variables on the adoption of gully plugs and buffer strips given varying land slopes. Tables 5 to 8 present the statistical results from the analysis. The sign of the coefficients in tables 5 and 7 provide the general direction of change in the adoption of the conservation practices in response to an increase in the associated independent variable. The values shown in tables 6 and 8 provide the marginal effects as probabilities in movement between categories of adoption from a change in the independent variable.

An overall statistically significant relationship $(p<0.01)$ between the independent variables and the adoption of conservation practices was verified in each equation using a Wald $\chi^{2}$ test (tables 5 and 7).Variance inflation factors were less than six (not shown), confirming multicollinearity among the independent variables was not a concern.

As hypothesized, the relationship between the perceived effectiveness of a conservation practice and use of that practice was significant $(p<0.01)$ in most cases. Respondents perceiving the effectiveness of buffer strips as low decreased their use of buffer strips across all landscapes, compared to respondents perceiving effectiveness as medium (table 7). For example, for land exhibiting a slight slope, the probability of buffer strips not being used by those perceiving their effectiveness as low increased by 0.32 , and the probability of being used some decreased by 0.23 (table 8). The marginal probability of buffer strips being used by those perceiving their effectiveness as low increased as the slope of land increased. For land with moderate and high slopes, the use of gully plugs by respondents perceiving their effectiveness as low was not significantly $(p<0.05)$ different from respondents perceiving their effectiveness as medium (table 5).

As the perception of the effectiveness of gully plugs (table 5) or buffer strips (table 7) went from moderate to high, the use of the conservation practice also increased across all landscapes. The perception of a high level of effectiveness for gully plugs on land with a moderate slope increased the probability of them being used often by 0.17 , being used some by 0.28 , and decreased the probability of not being used by 0.45 (table 6). For land with a slight slope, the perception of high effectiveness of gully plugs decreased their probability of being used none by 0.61 and increased their probability of being used some and often by 0.50 and 0.11 , respectively. Similar results were obtained for the use of buffer strips.

Education, years of managing a farm, and whether the respondent farmed full-time 
Table 4

Frequency of use and perceived effectiveness of gully plugs and buffer strips on respondents' farmland of different slopes.

\begin{tabular}{|c|c|c|c|c|c|c|}
\hline \multirow[b]{3}{*}{ Survey responses } & \multicolumn{6}{|l|}{ Slope of land } \\
\hline & \multicolumn{3}{|l|}{ Gully plugs } & \multicolumn{3}{|l|}{ Buffer strips } \\
\hline & $\begin{array}{l}\text { None-to-slight } \\
\text { (0\% to } 5 \%)\end{array}$ & $\begin{array}{l}\begin{array}{l}\text { Moderate } \\
\text { (6\% to 15\%) }\end{array} \\
\end{array}$ & $\begin{array}{l}\text { High } \\
\text { (>15\%) }\end{array}$ & $\begin{array}{l}\text { None-to-slight } \\
\text { (0 to } 5 \%)\end{array}$ & $\begin{array}{l}\text { Moderate } \\
\text { (6\% to 15\%) } \\
\end{array}$ & $\begin{array}{l}\text { High } \\
(>15 \%)\end{array}$ \\
\hline \multicolumn{7}{|c|}{ Frequency of use (percent of farmers) } \\
\hline None & $72 \%$ & $61 \%$ & $66 \%$ & $46 \%$ & $41 \%$ & $40 \%$ \\
\hline \multicolumn{7}{|c|}{ Perceived effectiveness (percent of farmers) } \\
\hline Low & $57 \%$ & $40 \%$ & $39 \%$ & $37 \%$ & $22 \%$ & $22 \%$ \\
\hline Medium & $24 \%$ & $35 \%$ & $30 \%$ & $30 \%$ & $42 \%$ & $32 \%$ \\
\hline High & $19 \%$ & $25 \%$ & $31 \%$ & $33 \%$ & $36 \%$ & $46 \%$ \\
\hline
\end{tabular}

were not, in general, significant indicators of the use of gully plugs or buffer strips for any landscape. The exception was that years of managing exhibited a negative relationship with gully plug use on moderate land slope, but the marginal impacts were nominal (table 6).
The size of farm (TOTAC) was not a significant determinant of buffer strips (table 7) but was for gully plugs on moderate and highly sloped lands (table 5). The greater the acreage being farmed, the more likely the respondent was to use gully plugs. This result may be influenced by economies of scale, by the notion that larger farms have a higher probability of having environmentally sensitive land, or perhaps there are just more gully plugs because there is more land.

The percentage of farmed acreage that was leased had a tendency to decrease the use of gully plugs on higher sloped land and increase the use of buffer strips on slight and moderately sloped land. Though the mar-

\section{Table 5}

Regression estimates for use of gully plugs on land with different slope levels.

\begin{tabular}{|c|c|c|c|c|c|c|}
\hline \multirow[b]{3}{*}{ Variable } & \multicolumn{6}{|c|}{ Dependent variables GPuse $_{i} \dagger$ with $i=$ land with slope of } \\
\hline & \multicolumn{2}{|l|}{ Slight ( $0 \%$ to $5 \%)$} & \multicolumn{2}{|c|}{ Moderate (5\% to $15 \%)$} & \multicolumn{2}{|l|}{ High (>15\%) } \\
\hline & Estimate & se & Estimate & se & Estimate & se \\
\hline GPeffect $_{i j}$ when $j=\mathrm{L}$ & $-1.3789 * * *$ & 0.3330 & -0.3951 & 0.2686 & -0.1162 & 0.2761 \\
\hline GPeffect $_{i j}$ when $j=\mathrm{H}$ & $2.853 * * *$ & 0.4040 & $1.9304 * * *$ & 0.345 & $1.2692 * * *$ & 0.3532 \\
\hline FT & 0.2233 & 0.3602 & 0.305 & 0.3338 & 0.1778 & 0.3462 \\
\hline$E D$ & -0.0026 & 0.0041 & 0.001 & 0.0021 & 0.0023 & 0.0074 \\
\hline FINSTRESS & $0.432 \times 10^{-4}$ & 0.0015 & -0.001 & 0.0012 & $-0.0032 * *$ & 0.0013 \\
\hline REGULATION & -0.2284 & 0.2880 & $-1.0576 * * *$ & 0.2492 & $-0.8082 * * *$ & 0.2573 \\
\hline IMPLEMENT & -0.2170 & 0.4629 & 0.4298 & 0.446 & 0.7239 & 0.5101 \\
\hline XRISK & 0.0020 & 0.0012 & -0.0021 & 0.0015 & 0.0016 & 0.0013 \\
\hline HERITAGE & 0.0015 & 0.0010 & 0.0007 & 0.0007 & 0.0004 & 0.0008 \\
\hline PROFIT & -0.0006 & 0.0008 & $-0.0012 *$ & 0.0007 & -0.0001 & 0.0008 \\
\hline $\bar{n}$ & 377 & & 354 & & 338 & \\
\hline$X^{2}$ statistic & $130.70 * * *$ & & $86.05 * * *$ & & $51.11 * * *$ & \\
\hline \multicolumn{7}{|c|}{$\begin{array}{l}\text { † The dependent variables is GPuse }{ }_{i} \text {, defined as the use of gully plugs at none }(0) \text {, some }(1) \text {, and often (2) frequency of use, on } i=\text { level of land slope } \\
\ddagger \text { Variables defined in table } 1 . \\
\star p<.1 * * p<.05 * * * p<.01\end{array}$} \\
\hline
\end{tabular}


Table 6

Marginal effects of regression estimates for use of gully plugs on land with different slope levels.

\begin{tabular}{|c|c|c|c|c|c|c|c|c|c|}
\hline \multirow[b]{2}{*}{ Variable } & \multicolumn{9}{|c|}{ Marginal effects on dependent variables GPuse $_{i} \dagger$ with $i=$ land with slope of } \\
\hline & Prob§y $=0$ & Prob $y=1$ & Prob $y=2$ & Prob $y=0$ & Prob $y=1$ & Prob $y=2$ & Prob $y=0$ & Prob $y=1$ & Prob $y=2$ \\
\hline GPeffect $_{i j}$ when $j=\mathrm{L}$ & $0.2375 * * *$ & $-0.2215 * * *$ & $-0.0160 *$ & $0.0898 * * *$ & $-0.0724 * * *$ & -0.0174 & 0.0241 & -0.0172 & -0.0069 \\
\hline $\mathrm{GPeffectH}_{i j}$ when $\mathrm{j}=\mathrm{H}$ & $-0.6106 * * *$ & $0.4967 * * *$ & $0.114 * * *$ & $-0.4476 * * *$ & $0.2797 * * *$ & $0.1679 * * *$ & $-0.2951 * * *$ & $0.1805 * * *$ & $0.1146 * * *$ \\
\hline TOTAC & 0.0000 & 0.0000 & 0.0000 & 0.0000 & $0.0001 *$ & 0.0000 & $0.0001 * *$ & $0.0001 * *$ & 0.0000 \\
\hline$E D$ & 0.0005 & -0.0004 & 0.0000 & -0.0002 & 0.0002 & 0.0000 & -0.0005 & 0.0003 & 0.0001 \\
\hline FINSTRESS & 0.0000 & 0.0000 & 0.0000 & 0.0002 & -0.0002 & 0.0000 & $0.0007 * *$ & $-0.0005 * *$ & $-0.0002 *$ \\
\hline REGULATION & 0.0420 & -0.0392 & -0.0028 & $0.2466 * * *$ & $-0.1911 * * *$ & -0.0556 & $0.1738 * * *$ & $-0.1198 * * *$ & $-0.0541 * *$ \\
\hline IMPLEMENT & 0.0407 & -0.0380 & -0.0027 & $-0.0932 * * *$ & $0.0766 * * *$ & 0.0166 & $-0.1326 * * *$ & $0.0979 * * *$ & 0.0347 \\
\hline MAINTENANCE & 0.0520 & $-0.0485^{*}$ & -0.0035 & $0.2331 * * *$ & $-0.1741 * * *$ & -0.0590 & 0.1454 & -0.0979 & -0.0475 \\
\hline$\%$ LEASED & 0.0001 & -0.0001 & 0.0000 & -0.0002 & 0.0001 & 0.0000 & 0.0008 & -0.0005 & -0.0002 \\
\hline PROFIT & 0.0001 & -0.0001 & 0.0000 & 0.0003 & -0.0002 & -0.0001 & 0.0000 & 0.0000 & 0.0000 \\
\hline \multicolumn{10}{|c|}{$\begin{array}{l}\text { † The dependent variables is } \text { GPuse }_{i} \text {, defined as the use of gully plugs at none (0), some (1), and often (2) frequency of use, on } i=\text { level of land slope. } \\
\ddagger \text { Variable defined in table } 1 .\end{array}$} \\
\hline \multicolumn{10}{|c|}{$\begin{array}{l}\text { § Probability of dependent variable } y \text {. Values of } y \text { are defined in table } 1 \text {. } \\
* p<.1 * * p<.05 * * * p<.01\end{array}$} \\
\hline
\end{tabular}

Table 7

Regression estimates for use of buffer strips on land with different slope levels.

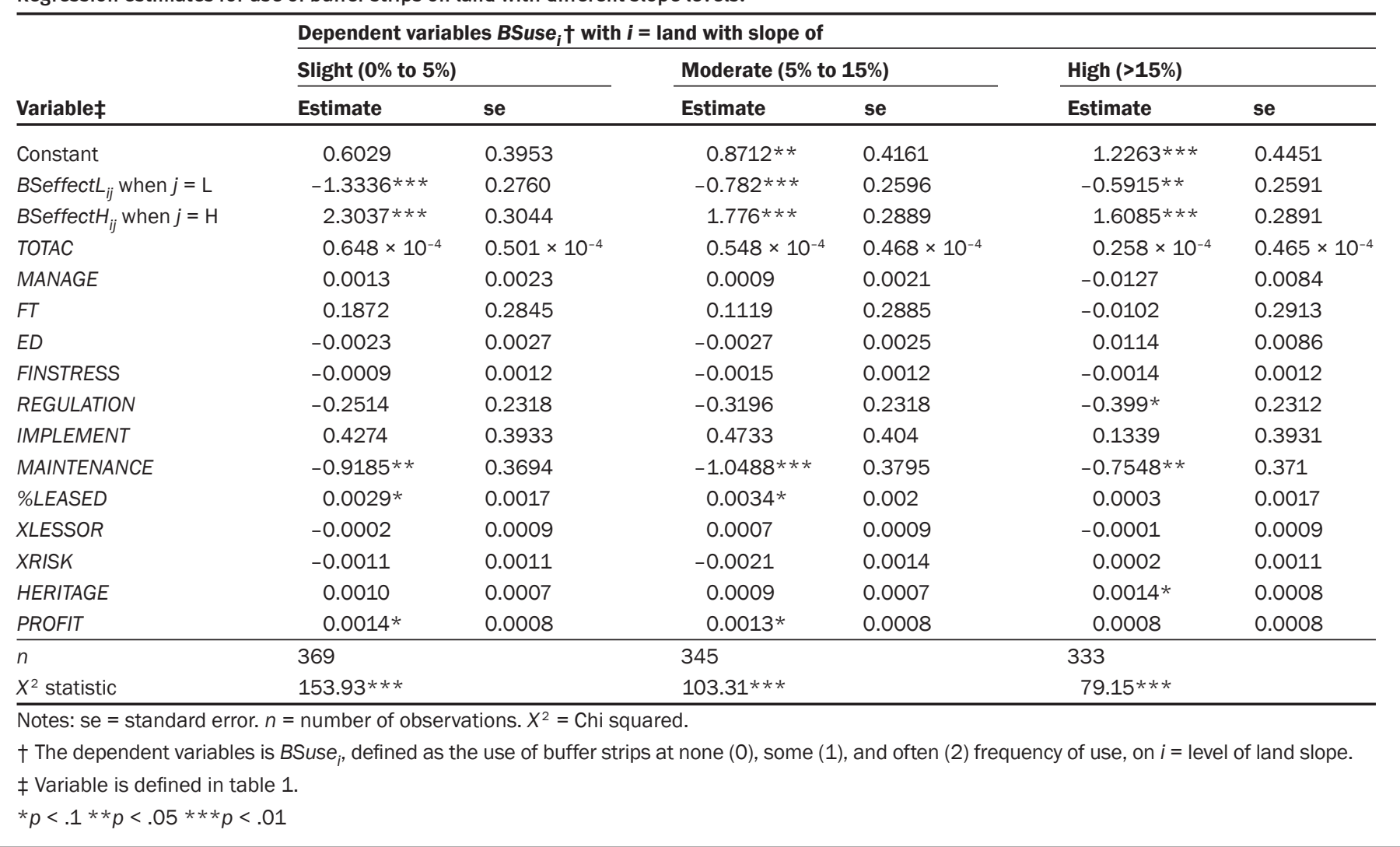


Table 8

Marginal effects of regression estimates for use of buffer strips on land with different slope levels.

\begin{tabular}{|c|c|c|c|c|c|c|c|c|c|}
\hline \multirow[b]{3}{*}{ Variable‡ } & \multicolumn{9}{|c|}{ Marginal effects on dependent variables $B$ use $_{i} \dagger$ with $i=$ land with slope of } \\
\hline & \multicolumn{3}{|c|}{ Slight ( $0 \%$ to $5 \%)$} & \multicolumn{3}{|c|}{ Moderate (5\% to $15 \%)$} & \multicolumn{3}{|l|}{ High (>15\%) } \\
\hline & Prob§ $y=0$ & Prob $y=1$ & Prob $y=2$ & Prob $y=0$ & Prob $y=1$ & Prob $y=2$ & Prob $y=0$ & Prob $y=1$ & Prob $y=2$ \\
\hline$B$ Seffect $H_{i j}$ when $j=\mathrm{H}$ & $-0.4308 * * *$ & $0.1329 * * *$ & $0.2979 * * *$ & $-0.3394 * * *$ & 0.0561 & $0.2832 * * *$ & $-0.3148 * * *$ & 0.0350 & $0.2799 * * *$ \\
\hline TOTAC & 0.0000 & 0.0000 & 0.0000 & 0.0000 & 0.0000 & 0.0000 & 0.0000 & 0.0000 & 0.0000 \\
\hline$E D$ & 0.0005 & -0.0004 & -0.0002 & 0.0006 & -0.0003 & -0.0003 & -0.0026 & 0.0010 & 0.0016 \\
\hline FINSTRESS & 0.0002 & -0.0001 & -0.0001 & 0.0004 & -0.0002 & -0.0002 & 0.0003 & -0.0001 & -0.0002 \\
\hline REGULATION & $0.0591 * * *$ & $-0.0383 * *$ & -0.0208 & $0.0723 * * *$ & $-0.0327 * * *$ & -0.0397 & $0.0903 * * *$ & $-0.0331 * * *$ & -0.0573 \\
\hline IMPLEMENT & $-0.1041 * * *$ & $0.0738 * * *$ & 0.0303 & $-0.1130 * * *$ & $0.0628 * *$ & 0.0502 & -0.0313 & 0.0133 & 0.0180 \\
\hline MAINTENANCE & $0.1973 * * *$ & $-0.1022 * * *$ & $-0.0951^{*}$ & $0.2099 * * *$ & $-0.0495 * * *$ & $-0.1604 * *$ & $0.1589 * * *$ & $-0.0364 * * *$ & -0.1225 \\
\hline HERITAGE & -0.0002 & 0.0002 & 0.0001 & -0.0002 & 0.0001 & 0.0001 & -0.0003 & 0.0001 & 0.0002 \\
\hline PROFIT & -0.0003 & 0.0002 & 0.0001 & -0.0003 & 0.0001 & 0.0002 & -0.0002 & 0.0001 & 0.0001 \\
\hline \multicolumn{10}{|c|}{$\begin{array}{l}\text { † The dependent variables is } B S \text { use } \\
\text {, defined as the use of buffer strips at none (0), some (1), and often (2) frequency of use, on } i=\text { level of land slope. } \\
\ddagger \text { Variables are defined in table } 1 .\end{array}$} \\
\hline
\end{tabular}

ginal effects of the percent of leased land were relatively small, respondents had a propensity to favor buffer strips over gully plugs on land they did not own. The importance of the landowner's willingness to invest in conservation practices (XLESSOR) and the importance respondents placed on the security of their lease (XRISK) did not significantly impact the use of gully plugs or buffer strips.

The farmer's financial condition was not a significant indicator of the adoption of either conservation practice considered, with the exception of gully plugs on highly sloped land. Neither was the cost of implementation of the practices an indicator of adoption. Conversely, the cost of maintenance was a significant indicator of the use of buffer strips across all landscapes and was a significant indicator of the use of gully plugs on moderately sloped land. The probability of never using buffer strips increased across landscapes for respondents who felt the cost of maintaining conservation practices played an important role in their undertaking that practice (table 8). Buffer strips require a fair amount of maintenance, as runoff water will often reach the edge of the strip and then erode down the edge of the strip rather than filter onto the strip. Farmers need to assure that field work does not make the land bordering the buffer strip lower than the buffer strip itself. If this occurs, extra work is required to maintain this bridge.

Respondents felt that regulatory requirements associated with conservation structures (REGULATION = 1) were a deterrent to the use of gully plugs on moderately and highly sloped land and to buffer strips on highly sloped land. The marginal effects were larger with gully plugs than with buffer strips. The probability of never using gully plugs on highly sloped land increased for respondents who agreed that regulation requirements were more effort than the conservation practice was worth, but this probability increased less for buffer strips. Regulations tended to impact gully plug use more on moderately sloped land compared to highly sloped land as the marginal effects were greater across alluse categories for the moderately sloped land (table 6).

The profit motive also impacted the use of gully plugs and buffer strips differently. The coefficients on PROFIT were positive for buffer strips but were negative for gully plugs across all landscapes, although not always statistically different from zero. Although the coefficients for the IMPLEMENT variable for both conservation practices were not significant, the difference in the PROFIT coefficient signs could relate to the rela- tive expensiveness of the two practices, with respondents more concerned with profitability shying away from gully plugs. However, the marginal effects are very small, suggesting profitability exerts a relatively small impact on gully plug or buffer strip use.

Although the signs on all coefficients were positive, the hope that respondents have for their children continuing to farm their land did not significantly influence the use of conservation practices, except for the use of gully plugs on highly sloped land. This result was somewhat surprising in that these structures are long-term investments intended to improve the integrity of the land and improve waterways for decades to come. Perhaps the multitude of other issues involved in the decision to implement these structures makes doing so for future generations less of a consideration, except under more sensitive circumstances that would require placing gully plugs on highly sloped land.

\section{Summary and Conclusions}

Many of the human capital variables Prokopy et al. (2008) identified and hypothesized to increase the capacity of farmers to adopt conservation practices were not statistically significant indicators of the adoption of gully plugs and buffer strips. Overall, the respondents' education level, management 
experience, and full-time commitment to farming did not influence their adoption of these conservation practices. Likewise, the hope respondents have for their children continuing to farm their land did not influence their use of gully plugs or buffer strips to any great extent.

Although an increase in the percentage of land leased was a deterrent to the adoption of gully plugs on highly sloped land, leasing was not a deterrent to the use of buffer strips on land with slight or moderate slopes. And while the majority of respondents leasing farmland agreed that the willingness of the lessor to invest in conservation practices was an important factor in the adoption of practices on those lands, and that the risk of losing a lease was likewise a deterrent, these factors were not particularly significant in determining the actual use of conservation structures on leased land. Given that almost half the land farmed by the respondents was leased, and given the importance respondents placed on the willingness of landowners to invest in conservation practices, more research should be aimed at the impact of the lessor on conservation. Educational programs and materials should also target lessors as key decision-makers on the land.

The main factor impacting the use of gully plugs and buffer strips was the producers' perceived effectiveness. If respondents perceived the effectiveness to be high, they were more likely to invest in the structures across all landscapes. This lends to the importance of field days and other events where farmers can witness the positive impact of these structures. To be effective at changing perceptions, longterm sites need to be maintained so producers can witness the use and dynamic impact of these conservation practices.

Cost of implementing gully plugs and buffer strips, which are typically addressed by government cost share programs, did not appear to be a deterrent to adoption. Government regulations and maintenance costs, conversely, were deemed more of a disincentive that should be addressed by government programs attempting to persuade farmers to adopt these practices.

One of the major limitations of this study is a failure to address the impact of government cost share programs on the adoption of gully plugs and buffer strips. The first impact of this omission is a probable misspecification error in the adoption models, which biases the variable coefficient estimates and their variance (Greene 2000). This could have impacted the tests of significance and led to fewer significant coefficients. The second implication is that the assessment of gully plug and buffer strip adoption in this study is not comprehensive. A suggested approach to rectify this oversight in future studies is to include questions to determine the respondents understanding of the cost of implementing, the cost of maintaining, the on-site benefits, the offsite benefits, and the regulatory requirements of each structure. After establishing this basis, respondents could then be asked the amount of cost share required for them to adopt each of these structures.

As with all site-specific studies, the variables that are significant in this study may not be replicable in other areas. This makes the task of policy management difficult as few variables can be applied to all areas. Continued assessment and review are important to keep in touch with the intent and sensitivity of the farmers being targeted with conservation programs.

\section{Acknowledgements}

Funding for this study was provided by a USDA Conservation Effects Assessment Project, 2004 to 2007 , Conservation Effects Assessment Project (agreement number 2004-48619-03119).

\section{References}

Asafu-Adjaye, J. 2008. Factors affecting the adoption of soil conservation measures: A case study of Fijian cane farmers. Journal of Agricultural and Resource Economics 33(1):99-117.

Carlson, J.E., B. Schnabel, C.E. Beus, and D.A. Dillman. 1994 Changes in the soil conservation attitudes and behaviors of farmers in the Palouse and Camas prairies: 1976-1990. Journal of Soil and Water Conservation 49(5):493-500.

Dasgupta, S., C. Meisner, and D. Wheeler. 2007. Is environmentally friendly agriculture less profitable for farmers? Evidence on integrated pest management in Bangladesh. Review of Agricultural Economics 29(1):103-118.

Dillman, D.A. 1978. Mail and telephone surveys: The total design method. New York, NY:Wiley-Interscience.

Dillman, D.A. 2000. Mail and telephone surveys:The tailored design method, 2nd edition. New York, NY: John Wiley \& Sons.

Dillman, D.A., and J.E. Carlson. 1982. Influence of absentee landlords on soil erosion control practices. Journal of Soil and Water Conservation 37(1):37-41.

Greene,W.H. 2000. Econometric analysis. Englewood Cliffs, NJ: Prentice Hall (4th ed).

Kim, S., J.M. Gillespie, and K.P. Paudel. 2005. The effect of socioeconomic factors on the adoption of best management practices in beef cattle production. Journal of Soil and Water Conservation 60(3):111-120.

Knowler, D., and B. Bradshaw. 2007. Farmers' adoption of conservation agriculture: A review and synthesis of recent research. Food Policy 32:25-48.

Lamba, P., G. Filson, and B. Adekunle. 2009. Factors affecting the adoption of best management practices in Southern Ontario. Environmentalist 29(1):64-77.

Lee, L.K., and W.H. Stewart. 1983. Land ownership and adoption of minimum tillage. American Journal of Agricultural Economics 65(2):256-64

Norris, E.P., and S.S. Batie. 1987. Virginia farmers' soil conservation decisions: An application of TOBIT analysis. Southern Journal of Agricultural Economics 19:79-90.

Pannell, D.J., G.R. Marshall, N. Barr, A. Curtis, F. Vanclay, and R. Wilkinson. 2006. Understanding and promoting adoption of conservation practices by rural landholders. Australian Journal of Experimental Agriculture 46:1407-1424.

Paudel, P.K., W.M. Gauthier, J.V.Westra, and L.M. Hall. 2008 Factors influencing and steps leading to the adoption of best management practices by Louisiana dairy farmers. Journal of Agricultural and Applied Economics 40(1):203-222.

Prokopy, L.S., K. Floress, D. Klotthor-Weinkauf, and A. Baumgart-Getz. 2008. Determinants of agricultural best management practice adoption: Evidence from the literature. Journal of Soil and Water Conservation 63(5):300-311, doi:10.2489/jswc.63.5.300.

Rahelizatovo, N.C., and J.M. Gillespie. 2004. The adoption of best-management practices by Louisiana dairy producers. Journal of Agricultural and Applied Economics 66(4):405-413.

Robinson, J.R., and T.L. Napier. 2002. Adoption of nutrient management techniques to reduce hypoxia in the Gulf of Mexico. Agricultural Systems 72:197-213.

SAS Institute. 2006. SAS Version 9.1. Cary, NC: SAS Institute. Soule, J.J., A. Tegene, and K.D. Wiebe. 2000. Land tenure and the adoption of conservation practices. American Journal of Agricultural Economics 82(4):993-1005.

Timmons, J.F. 1980. Protecting agriculture's natural resource base. Journal of Soil and Water Conservation 35(1):5-11.

Wu, J., and B.A. Babcock. 1998 . The choice of tillage, rotation, and soil testing practices: Economic and environmental implications. American Journal of Agricultural Economics 80:494-511. 